\title{
POPULARIZATION OF OBJECTS OF THE CULTURAL AND HISTORICAL HERITAGE OF THE REPUBLIC OF KAZAKHSTAN AS A FACTOR FOR THE DEVELOPMENT OF ETHNOCULTURAL TOURISM OF THE COUNTRY
}

\author{
Baurzhan ALDYBAYEV* \\ Kazakh Academy of Sports and Tourism, Department of Tourism \\ and Service, Almaty, Republic of Kazakhstan, e-mail: aldybayevb@bk.ru \\ Anastassiya GUBARENKO \\ Kazakh Academy of Sports and Tourism, Department of Tourism \\ and Service, Almaty, Republic of Kazakhstan, e-mail: gerseda @ mail.ru \\ Tatyana IMANGULOVA \\ Russian State University of Physical Education, Sport, youth and tourism (scolipe), \\ Department of Recreation and Sports-Health Tourism, Russian Federation, e-mail: tanya_geo@mail.ru
}

\section{Saltanat USSUBALIYEVA}

Kazakh Ablaikhan University of International Relations and World Languages, Department of International Tourism Management, Almaty, Republic of Kazakhstan, e-mail: salta-74@mail.ru

\section{Madina ABDIKARIMOVA}

Kazakh Academy of Sports and Tourism, Department of Tourism and Service, Almaty, Republic of Kazakhstan, e-mail: madina.abdikarimova@gmail.com

\begin{abstract}
Citation: Aldybayev, B., Gubarenko, A., Imangulova, T., Ussubaliyeva, S., \& Abdikarimova, M. (2021). POPULARIZATION OF OBJECTS OF THE CULTURAL AND HISTORICAL HERITAGE OF THE REPUBLIC OF KAZAKHSTAN AS A FACTOR FOR THE DEVELOPMENT OF ETHNOCULTURAL TOURISM OF THE COUNTRY. GeoJournal of Tourism and Geosites, 39(4spl), 1450-1460. https://doi.org/10.30892/gtg.394spl16-789
\end{abstract}

\begin{abstract}
This article is devoted to the research of world cultural heritage sites in the territory of Kazakhstan, their influence on tourist flows, and the formation of new routes in the direction of ethnocultural tourism. In the article, the authors anal yze the phenomenon of ethnocultural tourism development as a way of knowing the historical, cultural, and natural heritage of the country. In the course of research activities, a survey was conducted, priority objects for the development of ethno-cultural tourism in the Southern region of the Republic of Kazakhstan were identified. The result of the study was the development of a technological map of the route "Turkestan - echo of centuries", which will significantly affect the popularization of UNESCO's cultural and natural heritage, as well as the quality of excursion services along this route, which will und oubtedly have a positive impact on the formation of tourist flows of domestic and inbound tourism in Kazakhstan, and will also allow to prepare new directions within the framework of ethno-cultural tourism.
\end{abstract}

Key words: tourism, ethnocultural tourism, world cultural heritage, cultural and historical heritage, culture

\section{INTRODUCTION}

Currently, the process of globalization has an influence on almost all areas of common society. Without bias, this process contributes to the creation and development of tourist connections between different countries, when a vital part of the tourist flow has pronounced cultural motives of tourist activity (Butuzov, 2019). Recently, there has been a significant amount of interest in the values-based orientations of society, its distinctive characteristics, exoticism and identity, i.e. what significantly distinguishes the culture of one people from another or qualitative changes taking place in their historical development. Culture can contribute to a healthier society, facilitates civic involvement and gives tourists a reason to visit (Morar et al., 2020). Cultural tourism is one of the fastest growing and attracting tourism types in the world (Maaiah and Wouhoush 2020). The concept of ethnocultural tourism is becoming more and more popular. The development of new routes, the creation of technological maps of excursions, allows us to systematically develop this type of tourism in the country. It is justified that ethnocultural tourism, as a collection of tourism practices that demonstrate the most diverse sections of human existence in culture, plays one of the defining roles in the diversity of intercultural communication, familiarity with regional cultures and cognition of traditional ways, values and folk beliefs (Dashkova, 2021). Cultural tourism relies on culture, the natural environment, tends to use the original mechanisms of traditional forms (Adhika and Putra, 2020), forming a unique cultural landscape of the territory. The heart of ethnocultural tourism is the cultural heritage itself, namely, the spiritual, cultural, economic, and social capital of

\footnotetext{
* Corresponding author
} 
irreplaceable value. Heritage feeds modern science, education, and culture. Along with natural resources, this is the main basis for national self-respect and recognition by the world community. Therefore, ethnocultural tourism is certainly based on all the diversity of the country's heritage, while particular attention is paid to the world's natural and cultural heritage, as the highest level of recognition of the significance of objects that have a unique, outstanding value, not limited by one state. Today, the protection of heritage at both the global and national levels demands specific attention. The international conventions, recommendations, resolutions and other documents on heritage issues that existed at the time of the formation of the concept of world natural and cultural heritage surely testified to the significance that the safety of unique objects represented in the eyes of the peoples of the world, regardless of which nation they belong to.

According to statistics posted on the official UNESCO (United Nations Educational, Scientific and Cultural Organization) website: https://www.unwto.org/, as of 2021, there are 1,154 objects on the World Heritage List, of which 3 are delisted, 52 are in danger, 40 are transboundary, 897 cultural, 218 natural, 39 mixed in 167 member countries of the UNESCO Convention on the Protection of the World Cultural and Natural Heritage. Five following attractions of Kazakhstan are included in this list: Mausoleum of Khoja Ahmed Yasawi, Petroglyphs within the Archaeological Landscape of Tamgaly, Saryarka - Steppe and Lakes of Northern Kazakhstan, Silk Roads: the Routes Network of Chang'an-Tianshan Corridor, Western Tien-Shan. Each attraction corresponds to the characteristics of the world's cultural, natural, historical heritage, and tourist routes developed for the purpose of their popularization are directed at their preservation and propagation among the broad masses of the population. The development of inbound tourism for the Republic of Kazakhstan is a very urgent topic, as the tourism industry in Kazakhstan at the state level is recognized as one of the priority areas of the economy (Ayetov and Uruzbayeva, 2018). The specific strategic location of Kazakhstan favors the revival of tourism on the Silk Road. Within the adopted Concept for the Development of the Tourism Industry until 2020, the cluster of Southern Kazakhstan will be positioned as the "The Heart of Great Silk Road". Many ethnic groups, including Kazakh people have formed and have their ethno-cultural peculiarities (Kaimuldinova and Abdimanapov, 2014), which can become the basis of ethno-cultural tourism of the Republic of Kazakhstan. The key tourist products that will be developed in this cluster hold cultural tourism and tour, while the level of preservation of the intangible cultural population of the country also remains considerably high, which can guarantee the authenticity of the tourist environment.

\section{MATERIALS AND METHODS}

"Ethnocultural tourism" is a comparably new term that joins several concepts. In the globalization era, when the boundaries between ethnic groups become thin, and the value of authenticity is increasing more and more, the popularity of ethnocultural tourism is growing day by day, so today there are many interpretations of this term. The purpose of ethnocultural tourism gives the masses access to the traditions, customs, culture of a certain ethnic group. Also, it is a way to preserve what can be completely lost today. This is especially right for attractions that have an outstanding, unprecedented value for the whole world since they save the features of the cultural and historical development of the country for all the world. Thus, the phenomenon of "World Heritage" knows no bounds, it is an international concept that unites all the global monuments of the cultural and natural heritage, whose value goes far beyond the borders of one country. The main goal of this phenomenon is the safety and popularization of cultural and natural heritage objects in the conditions of progressive globalization. Now, the "ethnocultural tourism" term can be classified as a special direction of tourism that allows tourists to "immerse themselves" in the culture, traditions, customs of a certain nation living on the historical territory within one or several states. These terms are formed and have a number of unique peculiarities and there is no doubt, these types of tourism are based on science - ethnography (Belkov, 2014) which makes it possible to prepare a theoretical framework for the development of tourism (Cheboksarov and Cheboksarova, 1985). Thus, the works of experts, ethnographers, researchers have had a significant influence on the development of tourism and become the theoretical and methodological basis of this direction of tourism. Having a scientific basis, ethnographic tourism is actively developing in multiple countries and allows influencing the preservation of historical and cultural heritage monuments, as well as slow down the negative aspects of globalization processes that affect all areas of human life.

An ethnic group or ethnicity is a grouping of people who identify with each other based on shared attributes that distinguish them from other groups such as a common set of traditions, ancestry, language, history, society, culture, nation, religion, or social treatment within their residing area (People and Bailey, 2010). The "product" of the ethnic group's life is undoubtedly various monuments that represent both objects of tangible and intangible culture, they become the "basis" for planning new routes that completely show and popularize the heritage of the people, both at the regional and international level. The cultural, natural, historical tangible, and intangible heritage of the people is a resource that requires not only careful treatment but also measures to preserve it. In national science, the tangible cultural heritage has long been perceived almost as a synonym for the term "monument". In our view, the tangible (as well as spiritual) cultural heritage is a complicated sociocultural system that follows synergetic laws, actively interacts with the environment, and conveys certain information that changes in time and space. Therefore, culture, in the context of ethnographic tourism, is viewed as the foundation for the development of this direction of tourism, where the approach to historical and cultural heritage is combined with the modern, sustainable development of a particular region, state, or even a corner of the world. The cultural and natural heritage of the nation is the memory of the past life of the peoples, their historical development, the contemporary state, and prospects for popularization (Vedenin, 1995).

For the development of excursion and tourist activities, especially historical and cultural orientation, the research of the cultural heritage of a particular region is extremely important (Gubarenko et al., 2020). The problem of heritage is very relevant due to its essential role in preserving cultural diversity and, consequently, the sustainable development of modern 
society. Heritage issues are of interdisciplinary nature. At the same time, cultural heritage is viewed as an important factor of interethnic harmony, since the Republic of Kazakhstan is a multiethnic state (Karatabanov et al., 2020).

In the course of the research, the method of sociological survey was applied - the method of sociological research, which includes collecting and obtaining primary empirical data about certain theories, knowledge, and social facts that make up the research subject, through oral or written interaction between the researcher (interviewer) and a given set of respondents (interviewees, respondents) (Zerchaninova, 2006). This method was applied to identify the most popular heritage objects among the general population, entities of the tourism industry, and future specialists, students, and undergraduates of the Kazakh Academy of Sports and Tourism (KazAST). During the research, in several stages the authors have developed and prepared a training and tourist-excursion route "Turkestan - the Echo of Centuries" for students of the Faculty of Tourism (KazAST), which was systematically introduced into the professional activities of travel agencies as a new tourist offer. The method of the experiment, based on a direct test run of a route and being a source of experience and empirical data (Pickett, 2011), was formed in 2017 with the assistance of more than 70 students and 15 teachers of the Department of Tourism and Service of KazAST. Significant changes were made in May 2021, then the route was tested (Yemelyanov, 2001) taking into account the modern features of the development of the South Kazakhstan Region. The method of drawing up a technological map of a tourist and excursion route currently allows preparing information about the route as holistically and systematically as possible, taking into account the peculiarities of the excursion methodology (Lyuterovich and Yagofarov, 2016). So, all these methods were necessary to build a new tourist-excursion, educational and training route "Turkestan - the Echo of Centuries", which allows to actively popularize the UNESCO World Cultural Heritage among students of the Tourism educational program, as it is part of the educational process and is already being actively introduced as a tourist offer for domestic and inbound tourism of South Kazakhstan.

The methodology of this scientific and practical research can be presented in the form of the main stages (Figure 1).

\begin{tabular}{|c|c|c|}
\hline 1. CONDUCTING A SURVEY & $\begin{array}{l}\text { 2. ANALYSIS OF THE SURVEY } \\
\text { RESULTS }\end{array}$ & $\begin{array}{l}\text { 3. RESEARCH OF TOURIST SITES } \\
\text { IN THE REGION }\end{array}$ \\
\hline $\begin{array}{l}\text { 6. INTRODUCTION OF A TOURIST } \\
\text { ROUTE INTO THE TOURISM } \\
\text { INDUSTRY AS A NEW TOURIST } \\
\text { OFFER }\end{array}$ & $\begin{array}{l}\text { 5. CREATING A TECHNOLOGICAL } \\
\text { ROUTE MAP "TURKESTAN - ECHO } \\
\text { OF CENTURIES" }\end{array}$ & $\begin{array}{l}\text { 4. PREPARATION OF A TRAINING } \\
\text { ROUTE, PRIMARY DETOUR }\end{array}$ \\
\hline
\end{tabular}

Figure 1. Research stages (Source: compiled by the author)

The main six stages of scientific research are: 1 . Study of the potential of ethnographic tourism through conducting a survey; 2. Formation of ideas about the demand and popularity of cultural heritage objects of the country through the analysis of the survey results; 3. Objects of a specific region (South Kazakhstan) were studied; 4. A primary training route was drawn up in the region and a primary detour of the route was conducted; 5. A unique technological map of the route "Turkestan - echo of centuries" was created, along which the final detour was conducted; 6 . The introduction of this route into the professional activities of subjects of education and tourism. Thus, the finished tourist product can be used both as a training route and as a tourist offer

\section{RESULTS AND DISCUSSION}

The objects of the global historical, cultural and natural heritage of the countries participating in the UNESCO Convention are, first of all, a huge resource of world tourism in these countries, since the modern tourist strives to see something unique, something that can not be found anywhere else, something that distinguishes one country from another during the general globalization. The Republic of Kazakhstan is a large territory, in the vastness of which there is a big number of historical and cultural monuments that are precious not only for our country but also for the whole world. The natural resources of the republic are, first of all, unique natural monuments, specially protected natural territories, state national parks, nature reserves, bio-reserves, etc. All this is a unique heritage of our nation and the whole world, and therefore the preservation of this wealth for future generations, popularization in the world community, etc. becomes more and more significant. Kazakhstan joined the World Heritage Convention on April 29, 1994. Just then the process of inclusion into the list of objects has begun in our country, and from that moment it became possible to actively preserve and popularize objects that are valuable not only for one country but for the whole world.

A major factor in promoting the World Heritage Sites of the Republic of Kazakhstan is a step-by-step process of developing new tourist proposals taking into account the demands of society, which should include both identifying priority objects, testing them in the process of practical training of students of the Tourism educational program, and subsequent implementation as a new tourist product. To implement this approach, the authors of the research, specialists of the tourism industry and tourism education, developed the following algorithm of actions:

1. Conduct a sociological survey among interested and potentially interested respondents. The authors have conducted a survey among students of the Tourism Faculty of KazAST, employers, entities of the tourism industry in order to identify a priority UNESCO object for which a tourist and excursion route will be developed.

2. Develop a training tourist and excursion route for students of the Tourism educational program in order to test and form professional competencies in the field of tourism activities. 
3. Prepare a reference technological map of a tourist and excursion route, taking into account the specifics of the route, objects of tourist interest, methodological recommendations and explanations.

4. Introduce the route into the activity of tourist companies as a new tourist offer.

Thus, the route developed within the framework of this algorithm allows preparing a tourist-excursion and training route to UNESCO sites in the territory of Kazakhstan, which will be an active means of promoting the country's tourist brand and improving the quality of practice-oriented tourist education.

The survey was conducted in April 2020; the respondents were more than 100 students from the KazAST studying under the Tourism educational program (EP) and representatives of the tourism industry. A number of questions were developed for them to determine promising trends in the development of a tourist and excursion route (Figure 2). The answer to the first question "What is the main type of your activity?" allowed identifying students and professionals of the tourism industry. So, out of $100 \%$ of respondents, $77 \%$ were students of the Tourism EP, $8 \%$ were students of another EP, $11 \%$ were professionals of the tourism industry, $2 \%$ were professionals of another field of activity, $2 \%$ were other.

The second question was "Which of the UNESCO World Heritage Sites in the Republic of Kazakhstan do you consider the most promising for the development of domestic and inbound tourism?" The majority of respondents answered "Mausoleum of Khoja Ahmed Yasawi" - 37\%; 26\% - "Silk Roads: the Routes Network of Chang'an-Tianshan Corridor"; $19 \%$ - "Petroglyphs within the Archaeological Landscape of Tamgaly"; 10\% - "Western Tian Shan"; 8\% - "Saryarka Steppe and Lakes of Northern Kazakhstan."

The answers to the third question "What type of tourism do you consider the most promising in the Republic of Kazakhstan?" allowed us to determine the direction of the tourist and excursion route. A larger number of respondents $40 \%$ - chose ethnographic tourism as the most promising; $32 \%$ - educational tourism; $12 \%$ - sports tourism; $8 \%$ - business tourism and $8 \%$ - ecological tourism.

The fourth question "Which travel schedule for long distances ( 2 or more days) is preferable for you?" allowed us to determine that, in general, the main travelling movements in the daytime, and the night in a hotel are the most preferable and comfortable for the respondents. This approach will require the presence of not only the main attractions on the route, but also a sufficient number of additional objects to maintain the interest of the tourist and excursion group.
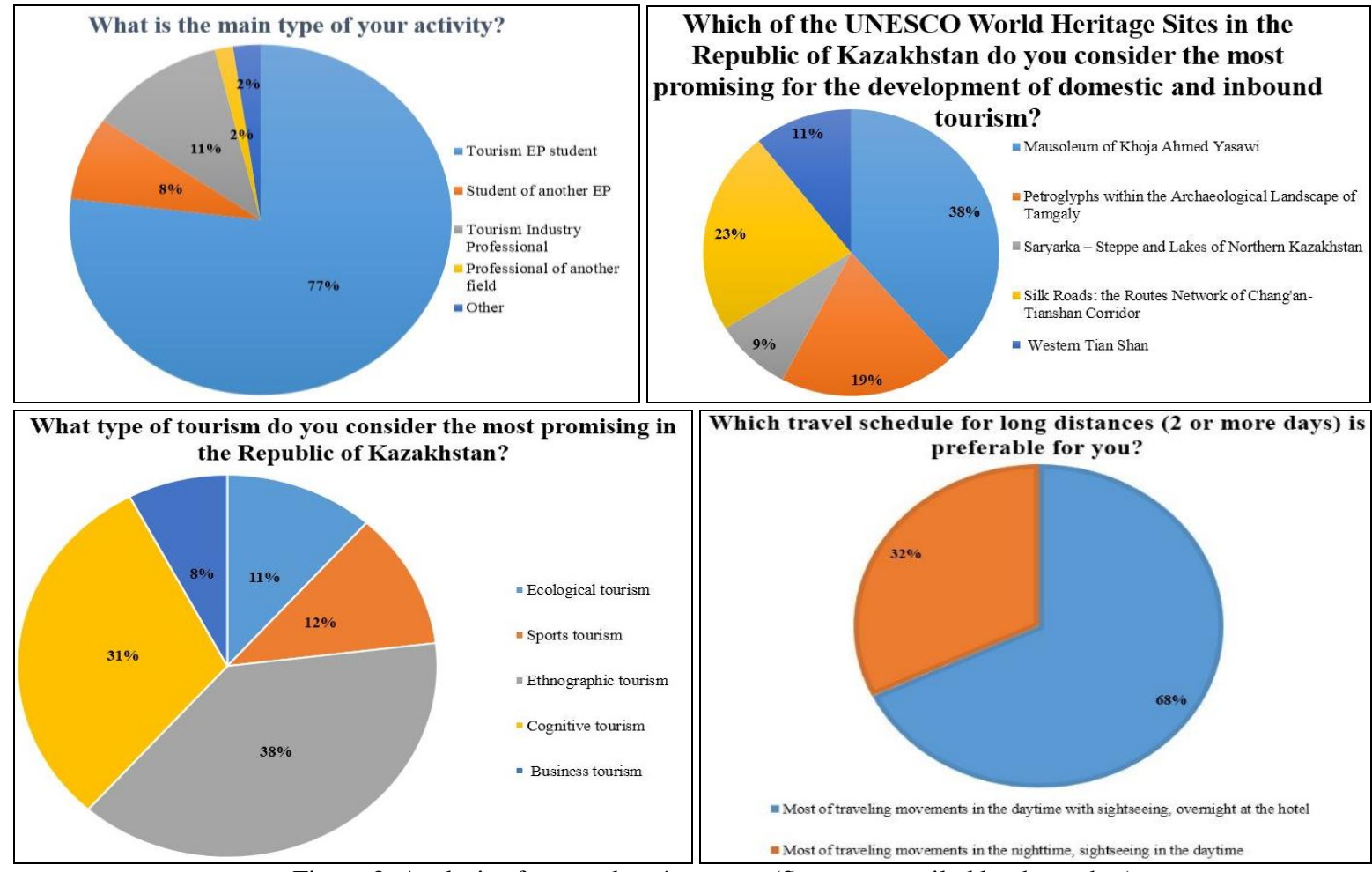

Figure 2. Analysis of respondents' answers (Source: compiled by the author)

Thus, in general, the conducted survey allowed designing a training, tourist-excursion route for the training of specialists in the Tourism educational program and tourist-excursion groups. The method of preparing such a route differs from the usual one, in that when developing it is necessary to take into account the extended time frame and the specifics of working in a group that has preliminary training. When analyzing the respondents' answers, the authors chose the direction of ethnocultural tourism with a visit to the main site (Mausoleum of Khoja Ahmed Yasawi, the Hilvet semi-underground mosque, the Visitor Center of Turkestan, Uly Dala Eli Innovation Center) and additional objects (the Mausoleums of Karakhan, Aisha Bibi and Babaji Khatun, the Al-Farabi Museum, the Otrar Museum, the Otrar settlement, Arystan-Bab Mausoleum, the modern city of Turkestan, the Mausoleum of Khoja Ahmed), selected taking into account the direction of the route: "the city of Almaty - the city of Taraz - the city of Shymkent - the city of Otrar - the city of Turkestan Almaty". The total length of the route is about $1768 \mathrm{~km}$ of the bus and $10 \mathrm{~km}$ of the walking route. 
The main segments of the route with distance in kilometers:

1) Almaty $43^{\circ} 16^{\prime} 39^{\prime \prime} \mathrm{N} 76^{\circ} 53^{\prime} 45^{\prime \prime} \mathrm{E}$ - Taraz $42^{\circ} 53^{\prime} 45.9168^{\prime \prime} \mathrm{N} 71^{\circ} 23^{\prime} 54.3480^{\prime \prime} \mathrm{E}$ (Mausoleums of Karakhan, Aisha Bibi and Babaji Khatun) - $491 \mathrm{~km}$ (about 6 hours in the picturesque area of Almaty and Zhambyl Region);

2) Taraz $42^{\circ} 53^{\prime} 45.9168^{\prime \prime} \mathrm{N} 71^{\circ} 23^{\prime} 54.3480^{\prime \prime} \mathrm{E}-$ Otrar $42^{\circ} 46^{\prime} 36^{\prime \prime} \mathrm{N} 68^{\circ} 22^{\prime} 08^{\prime \prime} \mathrm{E}$ (Shaulder) (Al-Farabi Museum, the Otrar Museum, Visitor Centre of the Oasis of Otrar) - 314 km (about 4 hours in Zhambyl and Turkestan Region, passing through the UNESCO Aksu-Zhabagly Nature Reserve and Sayram-Ugam National Park);

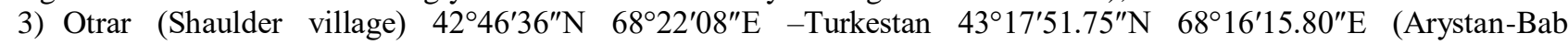
Mausoleum, city of Turkestan, Mausoleum of Khoja Ahmed Yasawi (a UNESCO Site), the Hilvet semi-underground mosque, Visitor Center (of Turkestan, Uly Dala Eli Information Center) is $75 \mathrm{~km}$ (about 1 hour 20 minutes on the road);

4) Turkestan $43^{\circ} 17^{\prime} 51.75^{\prime \prime} \mathrm{N} 68^{\circ} 16^{\prime} 15.80^{\prime \prime} \mathrm{E}$ - Domalak Ana Mausoleum $42^{\circ} 52^{\prime} 30^{\prime \prime} \mathrm{N} 69^{\circ} 40^{\prime} 11^{\prime \prime} \mathrm{E}, 162 \mathrm{~km}$ (about 2 hours on the way);

5) Domalak Ana Mausoleum $42^{\circ} 52^{\prime} 30^{\prime \prime} \mathrm{N} 69^{\circ} 40^{\prime} 11^{\prime \prime} \mathrm{E}-$ Almaty $43^{\circ} 16^{\prime} 39^{\prime \prime} \mathrm{N} 76^{\circ} 53^{\prime} 45^{\prime \prime} \mathrm{E}$ (possible stop in Shymkent, Taraz) - $721 \mathrm{~km}$ (about 9 hours of travel).

1.

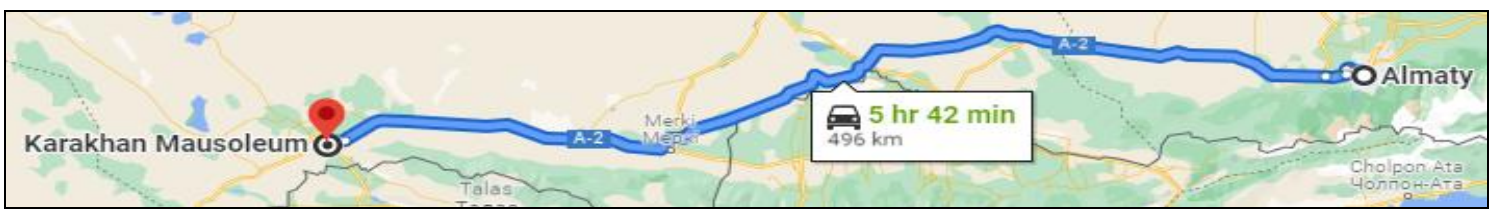

3.

2. OAsha Bibi Mausousoleum

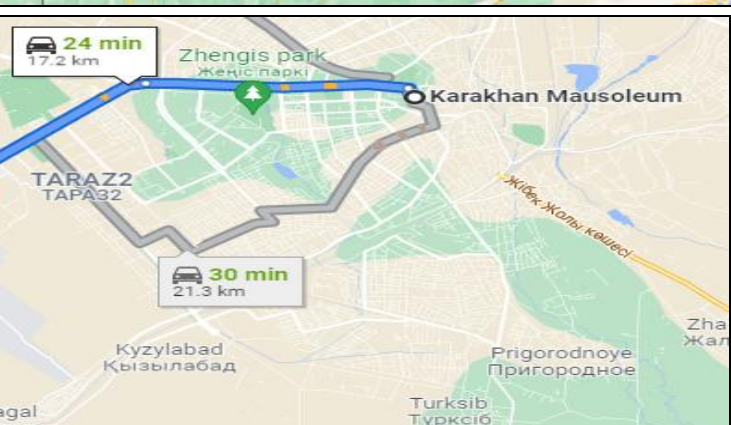

4.
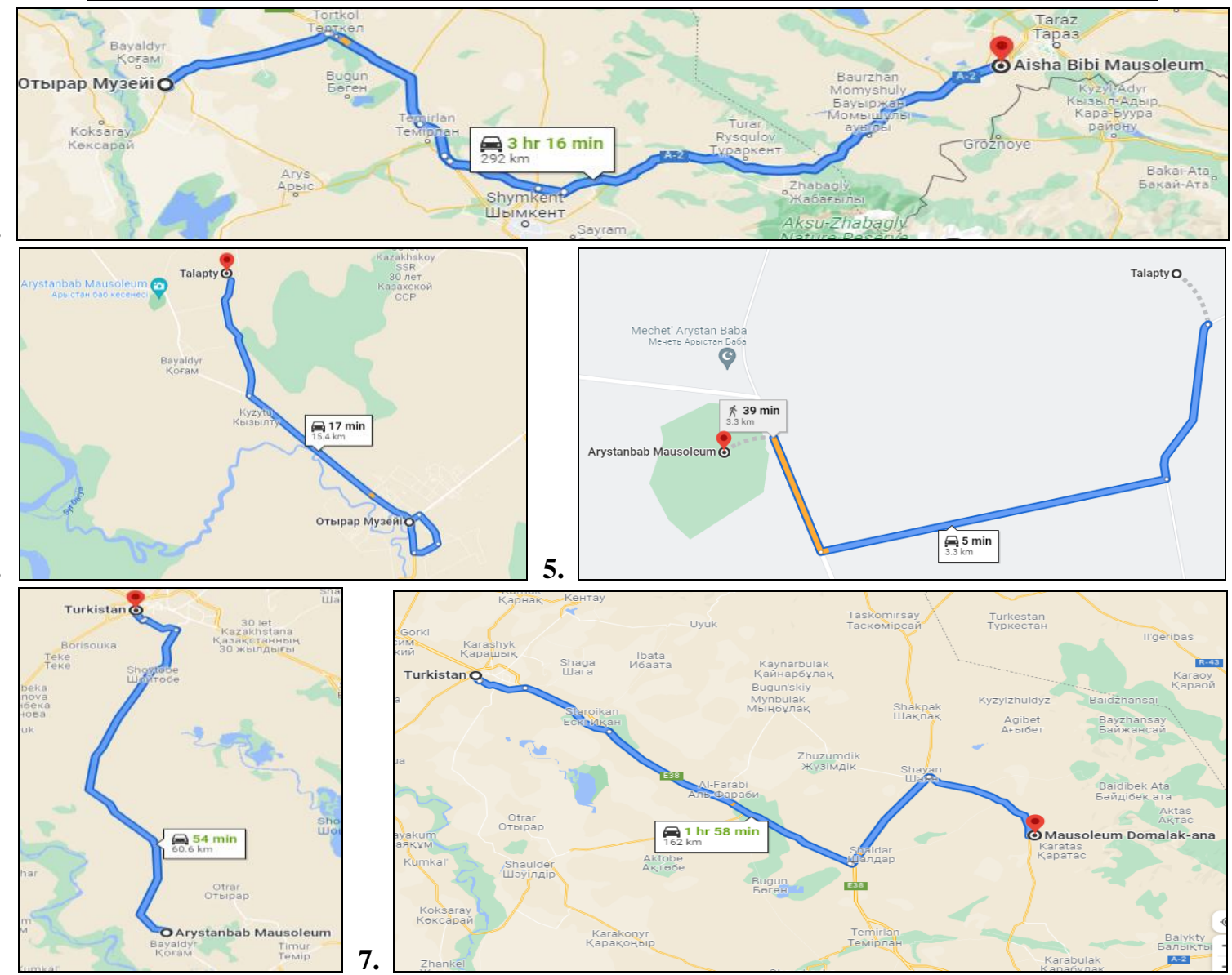

5.
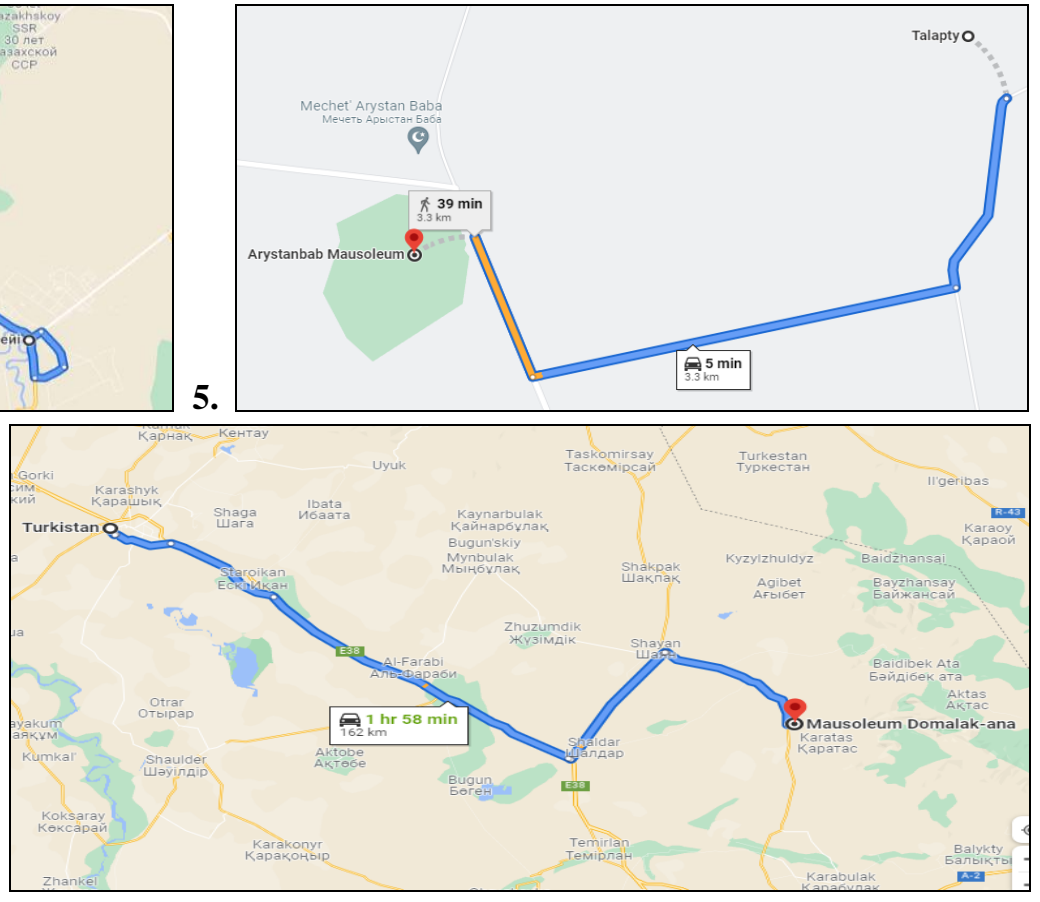

Figure 3. Route map of Almaty - the Mausoleums of Karakhan (Taraz) (1) - the Mausoleum of Aisha Bibi and Babaji Khatun (Taraz) (2) - Otrar Oasis Museum (Shaulder village) (3) - Otrar Information Center (Talapty village) - excavations of the Otrar Oasis (Talapty village) (4) - Arystan-Bab Mausoleum (5) - Turkestan (6) - Domalak ana Mausoleum (7) - (source Google Map). 
The time excluding excursions is about 22 hours, depending on weather conditions, the time can be adjusted. For the most correct calculation of the time spent on the route, excursion program, hygiene stops, as well as for the implementation of a professional approach to the development of tourist and excursion routes, the authors compiled a technological map of the excursion route "Turkestan - the Echo of Centuries".

The technological map of the tourist and excursion route consists of mandatory positions, filling in which the practitioner transmits not only the route of the group but also improves the quality of tourist and excursion services through methodological instructions. Such a map consists of the following:

1. the excursion route - with an indication of all the road stretches;

2. stops that are provided on the route with or without getting off the bus;

3. places of interest, with access to a walking tour or passing through, without getting off the bus (travel information);

4. the time spent on a particular stretch of the route, an excursion program, or other;

5. the name of the subtopics and the list of the main issues that allow the guide to make his excursion story and organize sightseeing in a quality manner;

6. organizational instructions necessary for the coordination of the activities of the tourist and excursion group;

7. methodological guidelines for the professional performance of the guide's work.

This technological map, designed in the course of empirical research in the educational and professional environment of tourism, allows not only to prepare a unique route but also makes it possible to develop various options for tourist travel, including or excluding additional elements. The scheme of the technological map is presented in Figure 3. This route was laid in 2017, and recorded, in 2018-2020, detailed work was carried out on drawing up a technological map of the route, currently, the KazAST Research Institute of Tourism is actively developing an educational and methodological manual for the work of guides on this route "Almaty - Turkestan - Almaty". In May 2021, a check of the route was conducted for training purposes, in August 2021 there was a final check. This route allows students to form the professional skills of a tour guide and a tourism manager, and tourists have a special chance to see unique objects under the protection of the Republic of Kazakhstan and UNESCO, as well as to examine the ethnocultural features of the country. So, the technological map of the excursion route: "Turkestan - the Echo of Centuries" has been created. Travel area: Southern Kazakhstan: Almaty, Zhambyl and Turkestan Regions. For all categories of tourists. Excursion type: educational, bus and walking. Seasonality: year-round

Duration: 1) Almaty - Taraz: $501 \mathrm{~km}$, time: $7 \mathrm{~h}$.

The excursion time at the Mausoleum of Karakhan and the Mausoleums of Aisha Bibi and Babaji Khatun: 1 hour

2) Taraz - Shaulder village: $304 \mathrm{~km}$, time: $3 \mathrm{~h} .40 \mathrm{~min}$.

The excursion time at the Al-Farabi Museum is 45 minutes

The excursion time at the Otrar State Archaeological Museum-Reserve is 45 minutes

3) Shaulder village - Talapty village: $12 \mathrm{~km}$, time: 15 minutes

The excursion time at the Otrar Oasis Information Center is 45 minutes

The excursion time at the Otrar Oasis site, the excavations of the Otrar settlement is 1 hour

4) Talapty village - Arystan-Bab: $5 \mathrm{~km}$, time: 7 minutes

The excursion time at the Arystan-Bab Mausoleum Memorial Site: 40 minutes

6) Arystan-Bab Mausoleum - Turkestan: $62 \mathrm{~km}$, time: 1 hour

The excursion time at the Evening City of Turkestan, caravansarai is 2 hours

The excursion time at the Mausoleum of Khoja Ahmed Yasawi is 1 hour and 20 minutes

The excursion time at the Hilvet semi-underground mosque is 30 minutes

The excursion time at the Excavations of the Ancient Bazaar is 30 minutes

The excursion time at the Visitor Center of Turkestan is 30 minutes

The excursion time at the Center of the Great Steppe Country is 45 minutes

7) Turkestan - Domalak Ana Mausoleum: 163 km, time: 2 hours

The excursion time at the Domalak ana Mausoleum is 45 minutes

8) Domalak Ana Mausoleum - Almaty: $721 \mathrm{~km}$, time: 8 hours 40 minutes

Route duration: 1) Bus - 1,768 km, round trip. 2) Walking - about $10 \mathrm{~km}$ round trip

Route: International highway "Almaty- the city of Tashkent" - Aisha Bibi village (with getting off) - Shymkent Temirlan village -Tortkol (turn to Shilik) - Shaulder -Talap village - Arystan-Bab Memorial Site - Turkestan - Domalak Ana Mausoleum - Almaty; Road: A-2, E38, R-58 (P-58)

The route "Turkestan - the Echo of Centuries" was built and formed in May 2017, the final check of the route taking into account new data was on May-August 2021. The departure time is calculated taking into account the characteristics of the group, vehicles, and weather conditions. On average, the route takes 2-3 days, overnight stays are carried out within the time frame. The first half of the route from Almaty to Turkestan in the evening involves a mandatory overnight stay in Turkestan, the second half of the route is designed for the second day, arrival in Almaty on the third day (overnight in the bus). This study was conducted taking into account the experience of the World Tourism Organization (UNWTO), which is a specialized agency of the United Nations for tourism (Madysheva et al., 2021).

When visiting shrines, it is essential to show tolerance, wear proper clothing covering the body, women should have a headscarf. Koran readings and prayers are frequently held at the main cultural and historical sites, which tourists can also witness. Also, guides need to have proper preparation for the excursion, to know the main subtopics (S/t), and to know the ethnocultural peculiarities of Kazakhstan at various historical stages. A special characteristic of this route is its educational and training orientation, which reveals the principles of practice-oriented tourist education (Gubarenko, 
2021) and can be applied not only for tourists but also for educational goals when training specialists in the tourism field, guides who are able to work at UNESCO World Heritage Sites, in accordance with WFTGA technologies. The route was developed with the active cooperation of national trainers who have successfully completed training at the courses of the World Federation of Tourist Guide Associations (WFTGA). The development of the technological map of the excursion "Turkestan - the Echo of Centuries" is a significant element in the creation of priority directions for the improvement of domestic and inbound tourism in the territory of modern Kazakhstan of an ethnocultural orientation.

Table 1 - The technological map (technological description) of the excursion route: "Turkestan - the Echo of Centuries"

\begin{tabular}{|c|c|c|c|c|c|c|}
\hline $\begin{array}{l}\text { Excursion } \\
\text { route }\end{array}$ & $\frac{0}{\frac{a}{\omega}}$ & $\begin{array}{l}\text { Places of } \\
\text { interest }\end{array}$ & : & \begin{tabular}{|l|} 
The name of the \\
sub-topics $(\mathrm{S} / \mathrm{t})$ \\
and the list of \\
main places \\
\end{tabular} & $\begin{array}{l}\text { Organizational } \\
\text { instructions }\end{array}$ & $\begin{array}{l}\text { Methodical } \\
\text { instructions }\end{array}$ \\
\hline $\begin{array}{l}\text { From } \\
\text { Almaty to } \\
\text { Taraz }\end{array}$ & \begin{tabular}{|l|} 
\\
\\
Pass- \\
ing \\
thro- \\
ugh
\end{tabular} & $\begin{array}{l}\text { Informati } \\
\text { on about } \\
\text { Almaty, } \\
\text { its thous- } \\
\text { and-year } \\
\text { history, } \\
\text { the city } \\
\text { places of } \\
\text { interest, } \\
\text { its role in } \\
\text { the forma- } \\
\text { tion and } \\
\text { functionin } \\
\text { g of the } \\
\text { Great Silk } \\
\text { Road } \\
\text { (GSR). }\end{array}$ & 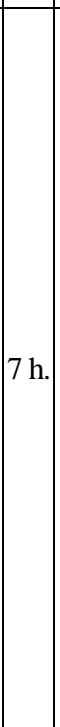 & $\begin{array}{l}\text { 1. S/t: The } \\
\text { history of } \\
\text { Almaty. } \\
\text { 2. S/t: The } \\
\text { physiographic } \\
\text { characteristics } \\
\text { and the history of } \\
\text { the Almaty } \\
\text { Region. } \\
\text { 3. S/t: The } \\
\text { physiographic } \\
\text { characteristics } \\
\text { and the history of } \\
\text { the Zhambyl } \\
\text { Region. }\end{array}$ & $\begin{array}{l}\text { When showing sites } \\
\text { of natural and } \\
\text { historical heritage, } \\
\text { slow down the } \\
\text { movement of the bus. } \\
\text { Use pointing words } \\
\text { and gestures. } \\
\text { Pay special attention } \\
\text { to the methods of } \\
\text { activating attention, } \\
\text { the distribution of } \\
\text { activity and time for } \\
\text { rest on a long route. }\end{array}$ & $\begin{array}{l}\text { Display technique is "movement along the object". Special } \\
\text { attention to the prerequisites for the emergence and } \\
\text { functioning of the Great Silk Road, its influence on the } \\
\text { formation of urban agglomerations, settlements, and centers } \\
\text { of culture. Traditions, culture, monetary relations on the } \\
\text { Kazakhstan segment of the GSR, the history of Almaty, its } \\
\text { thousand-year history, development, and current state, as } \\
\text { well as the role in the formation of a modern state. Leaving } \\
\text { the city and entering the Almaty Region, tell about the } \\
\text { peculiarities of the physical and geographical location, the } \\
\text { flora and fauna of the region, the peculiarities of historical } \\
\text { development, culture. Identify the main objects of the route } \\
\text { along the way: the Monument of Nauryzbai Batyr, } \\
\text { Anrakay Battle Stele, Uzynagash, Ungertas and also villages, } \\
\text { explaining their features, population, important dates and } \\
\text { events: Kaskelen, Shamalgan, Talgap, Samsy, Targap, } \\
\text { Beriktas, etc. When entering the Zhambyl Region, give a } \\
\text { historical reference and the physiographic characteristics of } \\
\text { the region, its features, and specifics, identifying the main } \\
\text { objects and focusing on the golden age of the GSR. }\end{array}$ \\
\hline $\begin{array}{l}\text { The } \\
\text { Mauso- } \\
\text { leum of } \\
\text { Karakhan }\end{array}$ & $\begin{array}{l}\text { Stop } \\
\text { with } \\
\text { gett- } \\
\text { ing } \\
\text { off } \\
\text { for a } \\
\text { gui- } \\
\text { ded } \\
\text { tour }\end{array}$ & $\begin{array}{l}\text { The } \\
\text { Mauso- } \\
\text { leum of } \\
\text { Karakhan }\end{array}$ & $\begin{array}{c}30 \\
\min \\
\cdot\end{array}$ & $\begin{array}{l}\text { 4. S/t: the } \\
\text { Mausoleum of } \\
\text { Karakhan }\end{array}$ & $\begin{array}{l}\text { Arrive at the stop, } \\
\text { announce the } \\
\text { departure time to } \\
\text { tourists. Build a } \\
\text { group in front of the } \\
\text { object in accordance } \\
\text { with the features of } \\
\text { the display time. }\end{array}$ & $\begin{array}{l}\text { The Mausoleum of Karakhan (Aulie-ata Mausoleum) (Kaz. } \\
\text { Karakhan kesenesi) is an architectural monument of the XI } \\
\text { century in the Kazakh city of Taraz. Built over the grave of } \\
\text { one of the representatives of the Karakhanid dynasty } \\
\text { (Nurgaliev, 1991), the mausoleum originally had a centric } \\
\text { composition and was covered with a dome. The entrance to the } \\
\text { early mausoleum was located under a gentle pointed arch, } \\
\text { which is highlighted by clinched masonry and outlined with } \\
\text { bricks laid flat. The arch was supported by } 3 / 4 \text { columns lined } \\
\text { with paired bricks. In a similar way, a deep entrance was } \\
\text { made, located behind an arched niche. The portal part was } \\
\text { outlined with brick with slightly protruding U-shaped arches. }\end{array}$ \\
\hline $\begin{array}{l}\text { The } \\
\text { Mausoleu } \\
\text { ms of } \\
\text { Aisha Bibi } \\
\text { and Babaji } \\
\text { Khatun }\end{array}$ & $\begin{array}{l}\text { Stop } \\
\text { with } \\
\text { gettin } \\
\text { g off } \\
\text { for a } \\
\text { guide } \\
\text { d } \\
\text { tour }\end{array}$ & \begin{tabular}{|l|} 
The \\
Mausoleu \\
ms of \\
Aisha \\
Bibi and \\
Babaji \\
Khatun
\end{tabular} & $\begin{array}{c}30 \\
\min \end{array}$ & $\begin{array}{l}\text { 5. S/t: The } \\
\text { Mausoleums of } \\
\text { Aisha Bibi and } \\
\text { Babaji Khatun }\end{array}$ & $\begin{array}{l}\text { Arrive at the stop, } \\
\text { announce the } \\
\text { departure time to } \\
\text { tourists. Build a } \\
\text { group in front of the } \\
\text { object in accordance } \\
\text { with the features of } \\
\text { the display time. }\end{array}$ & $\begin{array}{l}\text { Aisha-Bibi is a mausoleum of the Karakhanid era, built in the } \\
\text { XI-XII centuries, located in the village of Aisha-Bibi of the } \\
\text { Zhambyl District of the Zhambyl Region, } 18 \mathrm{~km} \text { from Taraz. } \\
\text { It is an architectural monument of national significance. } \\
\text { Special attention should be paid to the historical aspect of the } \\
\text { development of the Karakhanid era and the legend of } \\
\text { Karakhan, as well as the architectural features of these } \\
\text { objects, while emphasizing the exclusivity of the site. } \\
\text { Explain the reasons why the object was not included in the } \\
\text { UNESCO World Heritage List, with a pointing gesture to } \\
\text { demonstrate tiles XI-XII (server portal) comparing them with } \\
\text { the "new model" (Oshanov, 2014). }\end{array}$ \\
\hline $\begin{array}{l}\text { Taraz - } \\
\text { Shaulder } \\
\text { village }\end{array}$ & \begin{tabular}{|l|} 
pass- \\
ing \\
thr- \\
ough
\end{tabular} & $\begin{array}{l}\text { Information } \\
\text { about the } \\
\text { Turkestan } \\
\text { Region, } \\
\text { UNESCO } \\
\text { sites Aksu- } \\
\text { Zhabagly } \\
\text { Nature Re- } \\
\text { serve and } \\
\text { Say-ram- } \\
\text { Ugam Nati- } \\
\text { onal Park }\end{array}$ & \begin{tabular}{|c|} 
\\
$3 \mathrm{~h}$. \\
40 \\
$\min$ \\
\end{tabular} & $\begin{array}{l}\text { 6. S/t: Natural } \\
\text { Heritage of } \\
\text { Kazakhstan - } \\
\text { international } \\
\text { recognition }\end{array}$ & $\begin{array}{l}\text { The guide's story is } \\
\text { carried out by } \\
\text { sightseeing of objects } \\
\text { in the course of the } \\
\text { bus movement }\end{array}$ & $\begin{array}{l}\text { Display technique is "movement along the object". Special } \\
\text { attention should be paid to the history of the region's } \\
\text { development, its physical and geographical characteristics, } \\
\text { unique features of flora and fauna, as well as the UNESCO } \\
\text { natural heritage sites Aksu-Zhabagly Nature Reserve and } \\
\text { Sayram-Ugam National Park along which the route runs. It is } \\
\text { necessary to provide reliable and comprehensive data on the } \\
\text { specifics of these objects and their role in global biogenesis. }\end{array}$ \\
\hline
\end{tabular}




\begin{tabular}{|c|c|c|c|c|c|c|}
\hline $\begin{array}{l}\text { Al-Farabi } \\
\text { Museum }\end{array}$ & $\begin{array}{l}\text { Stop } \\
\text { with } \\
\text { gett- } \\
\text { ing } \\
\text { off } \\
\text { for a } \\
\text { gui- } \\
\text { ded } \\
\text { tour } \\
\text { in the } \\
\text { mu- } \\
\text { seum } \\
\end{array}$ & $\begin{array}{l}\text { "Spirituali } \\
\text { ty - Abu } \\
\text { Nasr Al- } \\
\text { Farabi } \\
\text { Museum" } \\
\text { State } \\
\text { Municipal } \\
\text { Managem } \\
\text { ent } \\
\text { Organizat } \\
\text { ion } \\
\text { (SMMO) } \\
\end{array}$ & min & $\begin{array}{l}\text { 7. S/t: Scientists } \\
\text { of the great } \\
\text { steppe }\end{array}$ & $\begin{array}{l}\text { Arrive at the stop, } \\
\text { form groups of } \\
\text { tourists with a } \\
\text { maximum of } 20 \\
\text { people. The tour is } \\
\text { carried out by the } \\
\text { museum's specialists } \\
\text { in Russian, Kazakh } \\
\text { and English by the } \\
\text { previous } \\
\text { appointment. }\end{array}$ & $\begin{array}{l}\text { The museum was opened in the homeland of the great scientist Abu } \\
\text { Nasr Al-Farabi. There are about } 6 \text { thousand exhibits related to the } \\
\text { life and work of the philosopher, mathematician, music theorist Nasr } \\
\text { Al-Farabi. About a thousand exhibits are exclusive. Special attention } \\
\text { should be paid not only to demonstration models, unique printed } \\
\text { materials, material and other sources, but also to historical facts in } \\
\text { the biography of the great scientist. Abu Nasr Muhammad ibn } \\
\text { Muhammad al-Farabi, a common abbreviation of the name - Al- } \\
\text { Farabi (in the Latinized form -Alpharabius; } 870 \text { or } 872 \text {, Farab or } \\
\text { Faryab, Khorasan (now Afghanistan) - between December } 14 \text {, } 950 \\
\text { and January 12, 951, Damascus, (modern Syria) - philosopher, } \\
\text { mathematician, music theorist, scientist of the East. One of the largest } \\
\text { representatives of medieval Eastern philosophy (Reisman, 2005). }\end{array}$ \\
\hline $\begin{array}{l}\text { Otrar State } \\
\text { Archaeolo } \\
\text { gical } \\
\text { Museum- } \\
\text { Reserve }\end{array}$ & \begin{tabular}{|} 
Stop \\
with \\
gett- \\
ing off \\
for a \\
guided \\
tour
\end{tabular} & \begin{tabular}{|l|} 
Otrar \\
State \\
Archaeolo \\
gical \\
Museum- \\
Reserve \\
\end{tabular} & $\begin{array}{c}45 \\
\text { min }\end{array}$ & $\begin{array}{l}\text { 8. S/t: Ancient } \\
\text { cities on the } \\
\text { route of the GSR }\end{array}$ & $\begin{array}{l}\text { Arrive at the stop, } \\
\text { announce the } \\
\text { departure time to tou- } \\
\text { rists. Give theoretical } \\
\text { information about the } \\
\text { museum, its exhibits } \\
\text { and museum objects. } \\
\end{array}$ & $\begin{array}{l}\text { In the village of Shaulder, which is located in the immediate vicinity } \\
\text { of the Otrar settlement and the Arystan-Bab Mausoleum, there is the } \\
\text { Otrar Museum, which widely presents ceramic dishes, candlesticks, } \\
\text { household items, household utensils, clothing, tools. An impressive } \\
\text { diorama "The Siege of Otrar". The museum in the village of } \\
\text { Shaulder keeps archaeological finds from the settlement of Otrar } \\
\text { and tells about the life of the city in the IX-XVIII centuries. }\end{array}$ \\
\hline $\begin{array}{l}\text { Shaulder - } \\
\text { Talapty } \\
\text { village }\end{array}$ & \begin{tabular}{|l|} 
Pa- \\
ssing \\
thr- \\
ough \\
\end{tabular} & $\begin{array}{l}\text { Surroundi } \\
\text { ng } \\
\text { landscape }\end{array}$ & $\begin{array}{c}15 \\
\min \end{array}$ & $\begin{array}{l}\text { 8. S/t: Ancient } \\
\text { cities on the } \\
\text { route of the GSR }\end{array}$ & $\begin{array}{l}\text { Give travel informa- } \\
\text { tion, mark the pano- } \\
\text { rama, pay attention to } \\
\text { the landscape }\end{array}$ & Travel information on the route. \\
\hline $\begin{array}{l}\text { Otrar } \\
\text { Visitor } \\
\text { Center }\end{array}$ & $\begin{array}{l}\text { Stop } \\
\text { with } \\
\text { gettin } \\
\text { g off } \\
\text { for a } \\
\text { guide } \\
\text { d } \\
\text { tour } \\
\end{array}$ & $\begin{array}{l}\text { Otrar } \\
\text { Visitor } \\
\text { Center }\end{array}$ & $\begin{array}{c}45 \\
\min \end{array}$ & $\begin{array}{l}\text { 8. S/t: Ancient } \\
\text { cities on the } \\
\text { route of the GSR } \\
\text { 7. S/t: Scientists } \\
\text { of the great } \\
\text { steppe }\end{array}$ & $\begin{array}{l}\text { Arrive at the stop in } \\
\text { front of the entrance } \\
\text { to the Visitor Center, } \\
\text { tell the tourists about } \\
\text { the arrival time. The } \\
\text { tour is conducted by } \\
\text { specialists of the } \\
\text { center }\end{array}$ & $\begin{array}{l}\text { The Otrar Visitor Center is a modern and comfortable place where } \\
\text { tourists can not only visit exhibition halls, get acquainted with } \\
\text { exhibits, etc., but also relax after a long trip. The Visitor Center has a } \\
\text { coffee area, a recreation area, a place for meetings and working } \\
\text { groups, an interactive zone where it is possible to watch a film about } \\
\text { the Otrar Oasis in comfortable conditions. On the second floor, } \\
\text { tourists can visit several temporary exhibitions and explore the } \\
\text { exhibits found at the excavation site in the ancient settlement of Otrar. }\end{array}$ \\
\hline $\begin{array}{l}\text { Otrar } \\
\text { Oasis }\end{array}$ & $\begin{array}{l}\text { Stop } \\
\text { with } \\
\text { gettin } \\
\text { g off }\end{array}$ & $\begin{array}{l}\text { Otrar } \\
\text { Settlemen } \\
\mathrm{t}\end{array}$ & $1 \mathrm{~h}$. & $\begin{array}{l}\text { 8. S/t: Ancient } \\
\text { cities on the } \\
\text { route of the GSR } \\
\text { 9. S/t: Otrar } \\
\text { Oasis }\end{array}$ & $\begin{array}{l}\text { Arrive at the stop, } \\
\text { announce the } \\
\text { departure time to } \\
\text { tourists. Use a } \\
\text { descriptive } \\
\text { movement to show } \\
\text { the panorama. Use } \\
\text { the event } \\
\text { reconstruction } \\
\text { technique. }\end{array}$ & $\begin{array}{l}\text { Give a historical reference about Otrar, as one of the oldest cities in } \\
\text { Central Asia. In Arabic sources, the city is called Farab. The first } \\
\text { settlements on the site of the city appeared in the VIII century. The } \\
\text { city began developing rapidly, as it was located on one of the main } \\
\text { branches of the Silk Road. By the XII century, it has already been a } \\
\text { large trade center of crafts and art, where there were palaces, } \\
\text { caravansarais, and city blocks. One of the biggest attractions of the } \\
\text { city was the Mausoleum of Arystan-Bab, built by Timur. } \\
\text { Use the event reconstruction technique, showing the objects of the } \\
\text { city, wells, walls, houses, as well as what has already been } \\
\text { restored, for example, the central gate, moat, baths, etc. }\end{array}$ \\
\hline $\begin{array}{l}\text { Talap } \\
\text { village - } \\
\text { Arystan- } \\
\text { Bab } \\
\end{array}$ & \begin{tabular}{|l|} 
passi \\
ng \\
throu \\
gh \\
\end{tabular} & $\begin{array}{l}\text { Surroun- } \\
\text { ding } \\
\text { landscape }\end{array}$ & $\begin{array}{c}7 \\
\min \end{array}$ & $\begin{array}{l}\text { 8. S/t: Ancient } \\
\text { cities on the } \\
\text { route of the GSR }\end{array}$ & $\begin{array}{l}\text { Give travel informa- } \\
\text { tion, mark the pano- } \\
\text { rama, pay attention to } \\
\text { the landscape }\end{array}$ & Travel information on the route. \\
\hline $\begin{array}{l}\text { Arystan- } \\
\text { Bab } \\
\text { Mausoleu } \\
\text { m } \\
\text { Memorial } \\
\text { Site }\end{array}$ & $\begin{array}{l}\text { Stop } \\
\text { with } \\
\text { gettin } \\
\text { g off }\end{array}$ & $\begin{array}{l}\text { Arystan- } \\
\text { Bab } \\
\text { Mausoleu } \\
\text { m }\end{array}$ & $\begin{array}{c}40 \\
\min \end{array}$ & $\begin{array}{l}\text { 10. Islam in the } \\
\text { territory of the } \\
\text { GSR } \\
\text { 11. Architecture } \\
\text { of GSR objects }\end{array}$ & $\begin{array}{l}\text { Arrive at the stop, } \\
\text { announce the } \\
\text { departure time to } \\
\text { tourists. Determine } \\
\text { the places for } \\
\text { ablution, the dress } \\
\text { code, and help } \\
\text { tourists with } \\
\text { maximum tolerance. }\end{array}$ & $\begin{array}{l}\text { Give information about the personality of Arystan-Bab, a } \\
\text { spiritual teacher, Sufi of Otrar, Sayram, Turkestan (Yassy). } \\
\text { Legends call him the teacher and spiritual mentor of Khoja } \\
\text { Ahmed Yasawi. Arystan-Bab, dying, gave him an amanat from } \\
\text { a persimmon bone. Tell a legend. The mausoleum is a historical } \\
\text { and cultural monument of architecture for tourists, a place of } \\
\text { worship for the Muslim community, spiritual food for the } \\
\text { people, the national cultural treasure of the country, the basis of } \\
\text { spiritual traditions, national value. The mausoleum of Arystan- } \\
\text { Bab has been restored for many centuries. It is assumed that he } \\
\text { lived in the XI-XII centuries. (It is possible to perform namaz). }\end{array}$ \\
\hline $\begin{array}{l}\text { Arystan- } \\
\text { Bab - } \\
\text { Turkestan }\end{array}$ & $\begin{array}{l}\text { Pass- } \\
\text { ing } \\
\text { thr- } \\
\text { ough }\end{array}$ & $\begin{array}{l}\text { Surroundi } \\
\text { ng } \\
\text { landscape }\end{array}$ & $1 \mathrm{~h}$ & $\begin{array}{l}\text { 8. S/t: Ancient } \\
\text { cities on the } \\
\text { route of the GSR } \\
\text { 10. Islam in the } \\
\text { territory of the } \\
\text { GSR }\end{array}$ & $\begin{array}{l}\text { Give travel } \\
\text { information, mark the } \\
\text { panorama, pay } \\
\text { attention to the } \\
\text { landscape }\end{array}$ & Travel information on the route. \\
\hline $\begin{array}{l}\text { Evening } \\
\text { Turkestan }\end{array}$ & \begin{tabular}{|l|} 
Stop \\
for \\
excur \\
sions \\
and \\
over \\
\end{tabular} & \begin{tabular}{|l|} 
Turkestan \\
in the \\
evening \\
time. \\
Keruen \\
Sarai \\
\end{tabular} & $2 \mathrm{~h}$. & $\begin{array}{l}\text { 8. S/t: Ancient } \\
\text { cities on the } \\
\text { route of the GSR }\end{array}$ & $\begin{array}{l}\text { Arrive and check in } \\
\text { at the hotel, prepare } \\
\text { tourists for a walk } \\
\text { around the evening } \\
\text { city. }\end{array}$ & $\begin{array}{l}\text { The largest multifunctional tourist complex in Central Asia } \\
\text { Keruen Sarai was opened in Turkestan, which is located in the } \\
\text { immediate vicinity of the Mausoleum of K. A. Yasawi. The site is } \\
\text { located on an area of } 20.5 \text { hectares. The complex includes a street } \\
\text { of merchants and artisans of the Silk Road, a "flying theater", an } \\
\text { amphitheater for horse shows, an oriental bazaar, shopping malls }\end{array}$ \\
\hline
\end{tabular}




\begin{tabular}{|c|c|c|c|c|c|c|}
\hline & $\begin{array}{l}\text { night } \\
\text { stays }\end{array}$ & & & & & $\begin{array}{l}\text { and boutiques, hotels and restaurants, a SPA and fitness center, a } \\
\text { cinema, a family entertainment center. At the same time, all the } \\
\text { structures are connected by a water channel, on which Boat } \\
\text { Parade - a theatrical show on the water - will be arranged. }\end{array}$ \\
\hline $\begin{array}{l}\text { Mausoleu } \\
\text { m of } \\
\text { Khoja } \\
\text { Ahmed } \\
\text { Yasawi }\end{array}$ & $\begin{array}{l}\text { Guid } \\
\text { ed } \\
\text { tour } \\
\text { at the } \\
\text { site }\end{array}$ & $\begin{array}{l}\text { UNESCO } \\
\text { World } \\
\text { Heritage } \\
\text { Site } \\
\text { Mausoleu } \\
\text { m of } \\
\text { Khoja } \\
\text { Ahmed } \\
\text { Yasawi }\end{array}$ & min & $\begin{array}{l}\text { 10. Islam in the } \\
\text { territory of the } \\
\text { GSR } \\
\text { 12. UNESCO } \\
\text { World Heritage } \\
\text { Site } \\
\text { 13. Turkestan - } \\
\text { the gate of the } \\
\text { Turks }\end{array}$ & $\begin{array}{l}\text { Arrive at the stop, } \\
\text { announce the } \\
\text { departure time to } \\
\text { tourists. Determine } \\
\text { the places for } \\
\text { ablution, the dress } \\
\text { code, and help } \\
\text { tourists with } \\
\text { maximum tolerance. } \\
\text { A panoramic show, } \\
\text { the placement of the } \\
\text { group, an excursion } \\
\text { in the complex itself } \\
\text { and related objects. } \\
\text { After the excursion } \\
\text { program, give the } \\
\text { tourists the } \\
\text { opportunity to freely } \\
\text { walk around the site, } \\
\text { after indicating the } \\
\text { time and place of } \\
\text { gathering. }\end{array}$ & $\begin{array}{l}\text { Give clear information about the historical period, the story should } \\
\text { complement the display, the fortress wall, the mausoleum, } \\
\text { architectural structures, the general infrastructure and the history of } \\
\text { Turkestan. Provide detailed information about the architecture and } \\
\text { appearance, prepare tourists and enter the mausoleum. At the same } \\
\text { time, with a pointing gesture, direct the attention of tourists to the } \\
\text { interior decoration, the layout of the building, and the objects located } \\
\text { in it. Emphasizing the importance of the mausoleum for the World } \\
\text { Cultural Heritage. The Mausoleum of Khoja Ahmed Yasawi in } \\
\text { Turkestan (until the XVI century, the city of Yassi) in Southern } \\
\text { Kazakhstan is a unique monument of the past of the Kazakh people. } \\
\text { In the XV-X centuries, Turkestan was the place of residence for the } \\
\text { Kazakh khans. The Mausoleum is on the grave of the poet and } \\
\text { preacher Khoja Ahmed Yasawi, located in Turkestan in the } \\
\text { Turkestan Region of Kazakhstan. It is the central object on the } \\
\text { territory of the historical and Hazrat Sultan, cultural museum- } \\
\text { reserve. The Hazrat Sultan Memorial Site, in addition to the } \\
\text { Mausoleum of Khoja Ahmed Yasawi itself, includes many other } \\
\text { structures built next to it in different years, namely a medieval bath } \\
\text { (monsha), a cell (hilvet) where Yasawi lived after he turned } 63 \text { years } \\
\text { old, the Mausoleum of Tamerlan's great-granddaughter and the } \\
\text { daughter of astronomer Ulugbek Rabia - Sultan Begim, the Mauso- } \\
\text { leum of the Kazakh Khan Yesim, shildehana and other ancient } \\
\text { monuments, among which the underground house for meditation of } \\
\text { Kumshik-ata has been miraculously preserved. In general, the entire } \\
\text { complex of objects is sometimes referred to as a "historical and } \\
\text { cultural reservation". The Mausoleum of Khoja Ahmed Yasawi } \\
\text { consists of eight rooms of various types, which are grouped around } \\
\text { the central, largest in the complex hall for tai kazan (Kaz. Kazan- } \\
\text { dyk): a mausoleum, a mosque, large and small palace halls (Kaz. } \\
\text { aksaray), a library (Kaz. kitapkhana) and an economic complex, } \\
\text { which includes a well (Kaz. kudykkhana), a dining room (Kaz. ash- } \\
\text { ana), residential and other premises. Relics and legends are of great interest. }\end{array}$ \\
\hline $\begin{array}{l}\text { The Hilvet } \\
\text { semi- } \\
\text { undergrou } \\
\text { nd } \\
\text { mosque }\end{array}$ & $\begin{array}{l}\text { Guid } \\
\text { ed } \\
\text { tour } \\
\text { at the } \\
\text { site }\end{array}$ & \begin{tabular}{|l} 
Semi- \\
undergrou \\
nd \\
mosque \\
of K. \\
A.Yasawi
\end{tabular} & $\begin{array}{c}30 \\
\text { min }\end{array}$ & $\begin{array}{l}\text { 10. Islam in the } \\
\text { territory of the } \\
\text { GSR } \\
\text { 13. Turkestan - } \\
\text { the gate of the } \\
\text { Turks }\end{array}$ & $\begin{array}{l}\text { Prepare tourists to } \\
\text { visit the place of wor- } \\
\text { ship with maximum } \\
\text { tolerance and compli- } \\
\text { ance with the necess- } \\
\text { ary standards. After the } \\
\text { tour, give the oppor- } \\
\text { tunity to buy souvenirs. }\end{array}$ & $\begin{array}{l}\text { The Hilvet semi-underground mosque is one of the medieval } \\
\text { religious architectural structures of the XII century, located } 120 \mathrm{~km} \\
\text { south of the Mausoleum of Khoja Ahmed Yassawi in Turkestan. } \\
\text { The word "Hilvet" in Arabic means "haluatun" - to be alone, to } \\
\text { worship the Creator alone. According to some sources, at the age of } \\
63 \text {, Khoja Ahmed Yassawi built the Hilvet mosque and spent the } \\
\text { rest of his life here, where he wrote Diwani Hikmet, Mirat-ul-Kulub, } \\
\text { Pakyrnama and his other works (Kalybay, 2011) }\end{array}$ \\
\hline $\begin{array}{l}\text { Excavatio } \\
\text { ns of the } \\
\text { ancient } \\
\text { bazaar }\end{array}$ & $\begin{array}{l}\text { Pano } \\
\text { rami } \\
\text { c } \\
\text { displ } \\
\text { ay }\end{array}$ & $\begin{array}{l}\text { Archaeol } \\
\text { ogical } \\
\text { site }\end{array}$ & $\begin{array}{c}30 \\
\mathrm{~min} \\
\cdot\end{array}$ & $\begin{array}{l}\text { 13. Turkestan - } \\
\text { the gate of the } \\
\text { Turks } \\
8 \text {. S/t: Ancient } \\
\text { cities on the } \\
\text { route of the } \\
\text { GSR }\end{array}$ & $\begin{array}{l}\text { Carry out a } \\
\text { panoramic view of } \\
\text { the excavation site, } \\
\text { to descend to the } \\
\text { covered, } \\
\text { demonstration part. }\end{array}$ & $\begin{array}{l}\text { Written and cartographic sources related to the history of Turkestan } \\
\text { of the XVII-XIX centuries mention the great Turkestan bazaar, } \\
\text { which for several centuries was the center of active social, political, } \\
\text { financial, economic and even cultural life of the city. Recently, our } \\
\text { scientists have found this famous Turkestan bazaar. The uniqueness } \\
\text { of the archaeological material lies in the fact that for the first time in } \\
\text { Kazakhstan, a late medieval oriental bazaar was discovered in a } \\
\text { large area with a well-preserved layout. This is the largest archaeo- } \\
\text { logical expedition, during which the territory of ancient Turkestan is } \\
\text { explored on an area of over } 30 \text { hectares, organized within the } \\
\text { scientific project "Restoration of historical objects of the Kultobe } \\
\text { settlement", implemented with the financial support of the Eurasian } \\
\text { Group (ERG). To date, the scientists of the Kazakh Research } \\
\text { Institute of Culture have managed to discover many interesting } \\
\text { archaeological sites of residential, public and religious purposes, } \\
\text { leading their history from the II century BC to the XIX century AD. }\end{array}$ \\
\hline $\begin{array}{l}\text { Turkestan } \\
\text { Visitor } \\
\text { Center }\end{array}$ & \begin{tabular}{|} 
Visit \\
to the \\
center \\
with \\
an ex- \\
cursi- \\
on pro- \\
gram \\
\end{tabular} & $\begin{array}{l}\text { Turkesta } \\
\text { n Visitor } \\
\text { Center }\end{array}$ & $\begin{array}{c}30 \\
\min \\
.\end{array}$ & $\begin{array}{l}\text { 13. Turkestan - } \\
\text { the gate of the } \\
\text { Turks } \\
8 . \text { S/t: Ancient } \\
\text { cities on the } \\
\text { route of the } \\
\text { GSR }\end{array}$ & $\begin{array}{l}\text { Conduct an excursion } \\
\text { in the Visitor Center, } \\
\text { provide tourists with } \\
\text { the opportunity to get } \\
\text { demonstration and } \\
\text { information materials } \\
\text { about the city and its } \\
\text { attractions. }\end{array}$ & $\begin{array}{l}\text { Visitor Center is a unique object built in the spiritual and } \\
\text { cultural center of Turkestan. Tourists coming to the ancient } \\
\text { city, first of all visit this center. There you can find full } \\
\text { information about the city, about the location of recreation } \\
\text { areas, parks and buildings, indicating how to get to these } \\
\text { places. There is also an exhibition hall with a large-scale model } \\
\text { of the city, a small exhibition, a cinema hall, souvenir shops. }\end{array}$ \\
\hline
\end{tabular}




\begin{tabular}{|c|c|c|c|c|c|c|}
\hline $\begin{array}{l}\text { The Uly } \\
\text { Dala Eli } \\
\text { Center }\end{array}$ & $\begin{array}{l}\text { Visit } \\
\text { to the } \\
\text { center } \\
\text { with } \\
\text { an } \\
\text { excur } \\
\text { sion } \\
\text { pro- } \\
\text { gram }\end{array}$ & $\begin{array}{l}\text { The } \\
\text { Country } \\
\text { of the } \\
\text { Great } \\
\text { Steppe } \\
\text { Center }\end{array}$ & $\begin{array}{c}45 \\
\min \end{array}$ & $\begin{array}{l}\text { 13. Turkestan - } \\
\text { the gate of the } \\
\text { Turks } \\
8 . \text { S/t: Ancient } \\
\text { cities on the } \\
\text { route of the GSR }\end{array}$ & $\begin{array}{l}\text { The tour takes place } \\
\text { in a modern center, } \\
\text { where tourists will } \\
\text { have the opportunity } \\
\text { to learn the historical } \\
\text { and cultural heritage } \\
\text { of the country in an } \\
\text { interactive form, as } \\
\text { well as have a good } \\
\text { time and relax }\end{array}$ & $\begin{array}{l}\text { The building is a 2-storey construction. On the first floor, there are } \\
\text { exhibition sites Metallurgy of the Great Steppe, Culture of } \\
\text { Horsemanship of the Great Steppe, Pearls of the Great Steppe, } \\
\text { Kazakhstan - the Cradle of the Turkic World and administrative } \\
\text { offices. On the second floor, there are exhibition sites Kazakh } \\
\text { Khanate, Urban Culture of the Great Steppe, the First President of } \\
\text { the Republic of Kazakhstan - Elbasy, Kazakhstan - the Birthplace } \\
\text { of Apples and Tulips, Kazakhstan of the Future. The underground } \\
\text { floor provides storage of exhibition equipment with associated } \\
\text { facilities, an interactive hall, a computer room, a conference room } \\
\text { and technical rooms. An interesting design solution is ceramic } \\
\text { granite floors under black marble with onyx inlaid granite in the } \\
\text { form of branched roots of the Baiterek Tree art object. There is wall } \\
\text { bas-relief in the form of a rock stone. Special attention should be } \\
\text { paid to the installed glass bridge with a length of } 12 \text { m in the Hall } \\
\text { of the Elbasy over the map of Kazakhstan. The heart of the Center } \\
\text { is the Turkic Hall, where a projection sphere with a height of } 14 \\
\text { meters and a radius of up to } 11 \text { meters has been created to } \\
\text { immerse the visitor in historical stories in 3D format. }\end{array}$ \\
\hline $\begin{array}{l}\text { Turkestan } \\
\text { - Domalak } \\
\text { Ana } \\
\text { Mausoleu } \\
\mathrm{m}\end{array}$ & \begin{tabular}{|l|} 
Pa- \\
ssing \\
thr- \\
ough
\end{tabular} & $\begin{array}{l}\text { The } \\
\text { surroundi } \\
\text { ng } \\
\text { landscape } \\
\text { and } \\
\text { cultural } \\
\text { heritage } \\
\end{array}$ & $2 \mathrm{~h}$. & $\begin{array}{l}\text { 14. S/t: culture of } \\
\text { the great steppe }\end{array}$ & \begin{tabular}{|l|} 
Prepare tourists for \\
the visit of an \\
upcoming object, \\
give information \\
about the early beliefs \\
and proto-religions of \\
the country. \\
\end{tabular} & $\begin{array}{l}\text { Travel information, data on shamanism, Tengriism, and other proto- } \\
\text { religions in the territory of modern Kazakhstan }\end{array}$ \\
\hline $\begin{array}{l}\text { Domalak } \\
\text { Ana } \\
\text { Mausoleu } \\
\mathrm{m}\end{array}$ & $\begin{array}{l}\text { Excu } \\
\text { rsion } \\
\text { with } \\
\text { gett- } \\
\text { ing } \\
\text { off }\end{array}$ & $\begin{array}{l}\text { Domalak } \\
\text { Ana } \\
\text { Mausoleu } \\
\text { m }\end{array}$ & $\begin{array}{c}45 \\
\min \\
.\end{array}$ & $\begin{array}{l}\text { 10. Islam in the } \\
\text { territory of the } \\
\text { GSR } \\
14 . \text { S/t: culture } \\
\text { of the great } \\
\text { steppe }\end{array}$ & $\begin{array}{l}\text { Arrive at the bus } \\
\text { stop, prepare } \\
\text { tourists for visiting } \\
\text { the local shrine, give } \\
\text { information about } \\
\text { the site. }\end{array}$ & $\begin{array}{l}\text { Domalak Ana Mausoleum is an architectural monument of the } \\
\text { XI century. The monument is located in the South Kazakhstan } \\
\text { Region, on the southern slope of Karatau, in the valley of the } \\
\text { Balabogen River. It was built over the grave of Nurila Ali } \\
\text { Sylankyzy, commonly known as Domalak Ana. Currently, she } \\
\text { is known as the Holy Mother. Women from all over } \\
\text { Kazakhstan visit this mausoleum to ask the Holy Mother for } \\
\text { the innermost. The surrounding area is a shady garden where } \\
\text { you can relax before a long road. }\end{array}$ \\
\hline $\begin{array}{l}\text { Domalak } \\
\text { Ana } \\
\text { Mausole- } \\
\text { um- } \\
\text { Almaty }\end{array}$ & \begin{tabular}{|l|} 
passi \\
ng \\
throu \\
gh
\end{tabular} & $\begin{array}{l}\text { Surroundi } \\
\text { ng } \\
\text { landscape }\end{array}$ & $\begin{array}{c}8 \mathrm{~h} \\
40 \\
\min \end{array}$ & $\begin{array}{l}\text { 8. S/t: Ancient } \\
\text { cities on the } \\
\text { route of the } \\
\text { GSR }\end{array}$ & $\begin{array}{l}\text { Give travel } \\
\text { information, show } \\
\text { the panorama, pay } \\
\text { attention to the } \\
\text { landscape and } \\
\text { determine the places } \\
\text { of stops, announce } \\
\text { the departure time to } \\
\text { tourists. }\end{array}$ & $\begin{array}{l}\text { Travel information on the route. Give general information and } \\
\text { answer the tourists' questions. }\end{array}$ \\
\hline
\end{tabular}

Note: The route has "main" objects, which are the purpose of the excursion route: the Otrar Oasis, the Mausoleum of Arystan-Bab, the Mausoleum of Khoja Ahmed Yasawi, and also, additional objects indicated in this route fully reveal the subtopics, and can be supplemented and coordinated in time.

Currently, tourists from all over the world are increasingly interested in cultural heritage objects, and the ethnocultural features of the regions. Their authenticity is a significant resource for promoting tourism in Kazakhstan throughout the world. The understanding of the importance of preserving cultural heritage sites should be expressed even during the training process when the student is actively involved in the professional process through practiceoriented technologies, which in the future will surely have a qualitative impact on the tourism specialist, his competence, and empathy for the national and global cultural, historical and natural heritage.

\section{CONCLUSIONS}

The development of tourism in any country directly depends on its cultural and natural heritage. At present, Kazakhstan faces the duty of preserving the past and present, through the establishment of a special structure for the preservation of not only World Historical and Cultural Heritage Sites, but also objects that have not yet been included in this list. This research work is one of the elements of large-scale research in the field of the development of Kazakhstan's ethnocultural tourism. The results obtained in the course of the research will become an extensive background for the development of ethnocultural tourism:

1. In the result of the conducted survey, it was concluded that there is a high demand for ethnocultural tourism in Kazakhstan, both among industry specialists and students studying under the Tourism educational program with the definition of the most popular objects for the present time.

2. The educational and training, tourist and excursion route "Turkestan - the Echo of Centuries" has been developed, which is actively applied in the training of specialists, guides, tourism managers at the Kazakh Academy of Sports and Tourism, as well as by the subjects of the tourism industry of Kazakhstan. 
3. A unique technological map of the training, tourist and excursion route "Turkestan - the Echo of Centuries" has been created; it fully reflects the current state of the route, including all the required information and methodological recommendations for present and future guides.

4. The final check of the route was carried out in May and August 2021 to accurately calculate all the elements of the route.

\section{Acknowledgments}

Kazakhstan has a powerful cultural potential for the development of the tourism industry, which can and should become an influential branch of its economy. Tourism promotes the popularization of historical and cultural monuments, strengthens the high authority of the republic, both in the country and abroad. The model of Kazakhstan's ethnocultural tourism, based on the application of the advantages of cultural heritage for tourism development, should be aimed at reviving forgotten traditions and types of art, building new centers of tourist interest, organizing specific types of routes. Tourist and excursion work can apply the full potential of the cultural heritage of sovereign Kazakhstan, and the creation of routes that will completely include places of unique value for the whole world, and will be used not only to develop a tourist offer but also to train future specialists in the tourism industry, will improve the quality of services provided, tourist offers and contribute to the further development of domestic and inbound tourism in Kazakhstan.

\section{REFERENCES}

Adhika, I.M., \& Putra, I.D.G.A.D. (2020). Reinvigorating cultural landscapes for planning cultural tourism in Bali. GeoJournal of Tourism and Geosites, 33(4spl), 1462-1469. https://doi.org/10.30892/gtg.334spl03-594

Ayetov, S., Uruzbayeva, N. (2018). Current Issues of Inbound Tourism in the Republic of Kazakhstan and Ways of Promotion. Journal of Environmental Management and Tourism, (Volume IX, Fall), 6(30), 1202-1209. https://doi.org/10.14505//jemt.v9.6(30).06

Belkov, P.L. (2014). Old and new in the study of the ethnographic heritage of N. N. Miklouho-Maclay: Essays on Historiography and Source Studies, St. Petersburg: Museum of Anthropology and Ethnography by Peter the Great (Kunstkamera), pp. 252, (in Russian).

Butuzov, A. (2019). Ethnocultural Tourism: a textbook. Moscow: KNORUS, pp. 248, (in Russian).

Cheboksarov, N.N., \& Cheboksarov, I.A. (1985). Peoples, races, cultures. Moscow, Nauka, pp. 272, (in Russian).

Dashkova, Y.V. (2021). Ethnocultural tourism in the context of intercultural communication Science almanac of Black Sea region countries. 26(2), 64-70.

Gubarenko, A., Kadyrbekova, D., Imangulova, T., Luterovich, O., \& Yespenbetov, N. (2020). Quest excursion, as interactive form of providing excursion services in Kazakhstan. GeoJournal of Tourism and Geosites, 32(4), 1402-1409. https://doi.org/10.30892/gtg.32431-587

Gubarenko, A.V. (2021). Development of the forms and methods of excursion service in the Republic of Kazakhstan. doctoral dissertation of philosophy (Ph.D.), 6D090200, Almaty, pp. 178, (in Russian).

Kaimuldinova, K., \& Abdimanapov, B. (2014). Traditional environmental management of Kazakhs as the Element of Sustainability Ethnic Groups. World Applied Sciences Journalthis link is disabled, 29(3), 383-387. https://doi.org/10.5829/idosi.wasj.2014.29.03.13863

Kalybay, J. (2011). Khoja Ahmed Yassawi (XI-XII). Zhuldyzdar Otbasy Anyz Adam Journal, pp. 41, (in Russian).

Karatabanov, R.A., Janaleyeva, K.M., \& Pashkov, S.V. (2020). Kazakhstan's Multiethnicity: factor of inter-ethnic tension and development of Cross-border tourism. GeoJournal of Tourism and Geosites, 29(2), 732-745. https://doi.org/10.30892/gtg.29227-502

Lyuterovic, O.G., \& Yagofarov, G.F. (2016). Excursion Activities in the Republic of Kazakhstan. Almaty, Service Pres s publishing house, pp. 301, (in Russian).

Maaiah, B.S., \& Wouhoush, O.N. (2020). Jordanian culture and traditions as a driving force for attracting Dutch tourists. GeoJournal of Tourism and Geosites, 33(4spl), 1450-1455. https://doi.org/10.30892/gtg.334spl01-592

Madusheva, A., Imangulova, T., Khudzhatov, M., Kalievna, Z.S., \& Niyazbekova, S. (2021). Management of Sustainable Development

Morar, C., Grama, V., Stupariu, I.M., Nagy, G., Boros, L., Tiba, Al., Gozner, M., \& Szabo-Alexi, S. (2020). Local perspectives over cultural tourism to heritage sites. The case study of Oradea fortress (Romania). GeoJournal of Tourism and Geosites, 33(4spl), 14701479. https://doi.org/10.30892/gtg.334spl04-595

Nurgaliev, R.N. (1991). Karakhana kumbez Kazakh SSR: a short encyclopedia. Language, Literature, Folklore, Art. Architecture, pp. 305, (in Russian).

Oshanov, O.Z. (2014). Taraz is the Pearl of the Silk Road. [A brief history of Taraz: from the Hunnic Horde to the Republic of Kazakhstan]. Almaty: Taimas, 179-181, (in Russian).

People, J., \& Bailey, G. (2010). Humanity: An Introduction to Cultural Anthropology. (9th ed.), Wadsworth Cengage learning, pp. 389.

Pickett, J.P. (2011). Empirical, The American Heritage Dictionary of the English Language (5th ed.). Houghton Mifflin, ISBN 978-0547-04101-8.

Reisman, D. (2005). Al-Farabi and the Philosophical Curriculum. Adamson, P., Taylor, R. The Cambridge Companion to Arabic Philosophy. Cambridge University Press, (in Russian).

Vedenin, Y.A. (1995). Actual problems of preserving natural and cultural heritage. M. Ros. Research Institute of Cultural and Natural Heritage, pp. 213, (in Russian)

Yemelyanov, B.V. (2001). Ekskursovedeniye, Moscow. Tourist Guidance. Soviet Sport, pp.214, (in Russian).

Zerchaninova, T.Y. (2006). A sociological survey Sociology. Dictionary, Yekaterinburg, UrAGS, pp. 64, (in Russian).

*** Convention for the Protection of the World Cultural and National Heritage, 16 November 1972.

*** Cultural Heritage State Program of the Republic of Kazakhstan for 2004-2006, Approved by the Decree of the President of the Republic of Kazakhstan dated January 13, 2003, No. 1277, Kazakhstanskaya pravda. November; Cultural Heritage Strategic National Project of the Republic of Kazakhstan for 2009-2011: Resolution of the Government of the Republic of Kazakhstan dated November 6, 2008, No. 1016 // Kazakhstanskaya pravda. 2008. November 5 (No. 336-337).

*** Of Tourism In Cross-Border Territories. Academy of Strategic Management Journalthis link is disabled, 20(2S), 1-9.

*** UNESCO World Heritage Site The official website of UNESCO (English). http://whc.unesco.org/en/list 